\title{
Рыцарские ордена Европы: Каталог выставки / Сост. Л. М. Гаврилова. М.: Государственный историко-культурный музей-заповедник «Московский Кремль», 2015. 432 с.
}

\begin{abstract}
Аннотаиия. Рещензируемое издание представляет собой значительную научную иенность. Автор рецензии приводит общую информачию, касающуюся как самой выставки, так и ее каталога, отмечает, ито основой экспозииии стала коллекиия профессора Московского университета А. Л. Хазина, которая является одним из лучших в мире частных собраний западноевропейских высших государственных наград. В рещензии анализируется содержание каталога, включал предисловие, написанное А. Л. Хазиным, введение, подготовленное куратором выставки и хранителем коллекиий музеев Московского Кремля Л. М. Гавриловой, текст каталога. Основная часть рещензии посвящена анализу информаиионной щенности каталога, а также подробной демонстрачии на ряде примеров того, как данные фалеристики позволяют уточнять те или иные факты прошлого. Рещензент выделяет наиболее иенные экспонаты выставки, среди которых т. н. оббединенные звезды нескольких орденов, орденские чепи и другие раритеты. Подчеркивается проработанная система представления экспонатов в каталоге и приводится рубрикатор, в соответствии с которым в издании представлена информаиия о каждой награде. Речензент отмечает и значимую роль, которую играют приложения к каталогу, в которых содержится справочная информачия о европейских наградных системах. Завершается рещензия исправлением отдельных неточностей каталога - неизбежных, как подчеркивает рещензент, при подготовке такого рода издания.
\end{abstract}

Ключевые слова: музеи Московского Кремля, фалеристика, награднал система, А. Л. Хазин, Л. М. Гаврилова, коллекиия, каталог выставки, экспонат, ордена, объединенная звезда орденов.

Review. The reviewed publication is a work of significant scientific value. The author of the review presents the general information pertaining to the exhibition itself, as well as to its catalogue, and notes that at the heart of the exhibition lies the collection of Moscow university professor A. L. Khazin, which is one of the foremost private collections of the highest WestEuropean state awards in the world. The reviewer analyses the content of the catalogue, including the collector's foreword to the publication and the introduction written by L. M. Gavrilova, the curator of the exhibition and of the Moscow Kremlin museum collections. A major part of the review is dedicated to the analysis of the informational value of the catalogue and demonstrates on a series of examples the value of phaleristics in elucidating various historical facts. The reviewer outlines the most important objects of the exhibition, among which are the so-called joint stars of several orders, order chains, and other rarities. The reviewer highlights the elaborated system of presenting the exhibits in the catalogue, set according to phaleristic categories and historical significance of the orders. Additionally, the reviewer points out the importance of the appendixes to the catalogue, which contain reference information on European award systems. The reviewer corrects some inexactitudes - unavoidable, as he notes, in the compilation of such publications.

Key words: Moscow Kremlin museums, phaleristics, award system, A. L. Khazin, L. M. Gavrilova, collection, exhibition catalogue, exhibit, orders, joint star of orders.

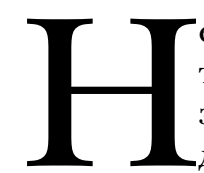

е всякие даже прекрасно изданные каталоги выставок заслуживают рецензии в научном журнале. Они полезны для читателя и посетителя, но далеко не всегда содержат новую, добытую исследованием информацию и открывают новые перспективы изучения материала. Рецензируемый каталог отно- сится к числу фундаментальных научных изданий, внося несомненный вклад в исследование и систематизацию сложных объектов фалеристики.

Основой выставки и ее каталога послужила коллекция известного фалериста, тонкого знатока наград академика РАХ и профессора МГУ А. Л. Хазина. Это одно из лучших в мире част- 


\section{Рецензии, библиография}

DOI: $10.7256 / 2222-1972.2015 .2 .16146$

ных собраний высших наград Великобритании, Франции, Австро-Венгрии, Германии, Италии, Испании, Португалии и Ватикана. Заботами Музеев Кремля, организатора выставки и ее директора Е. Ю. Гагариной к әкспозиции были добавлены жемчужины - знаки ордена Подвязки российского императора Александра II из Британской королевской коллекции, по статуту возвращаемые в Англию после смерти кавалера и впервые привезенные в Россию с согласия королевы Елизаветы II.

Несомненным достоинством выставки являлся способ экспонирования предметов - исключительно наглядный, позволяющий зрителю рассмотреть все особенности орденских знаков. Немаловажным «обрамлением» выставки служили также видеоматериалы с отлично подобранными видеорядом и текстами, а также специально изготовленные сувениры по тематике экспозиции.

Каталог открывается замечательным предисловием А. Л. Хазина, где он рассказывает, как его увлечение связано с семейной традицией, с наградами предков, выдающихся деятелей науки и политики. Рождение интереса переросло в увлечение, увлечение породило всестороннее знание предмета, которым в нашей стране обладают единицы. Именно глубокие и конкретные знания позволили точно ориентироваться в безбрежных просторах мировой фалеристики и создать коллекцию шедевров и символов эпохи. Справедливым лейтмотивом книги, обеспечивающим ее высокое гражданское значение, является утверждение, что система государственных наград наряду с флагом, гербом и гимном является символом державы. Награда отмечает подвиг или высокое общественное служение, является знаком признания и статуса человека. Потому знание наград - это постижение традиций и идейных устоев государства, способов его саморепрезентации, осуществления его связей с обществом, гражданином или подданным.

Куратор выставки и хранитель коллекций Музеев Кремля доктор исторических наук Л. М. Гаврилова в своем Введении справедливо отмечает значение частного коллекционирования в сохранении и систематизации памятников истории и культуры [с. 13]. Не только целые музейные собрания нередко создавались энтузиастами-коллекционерами, но и спасение памятников культуры - дело их рук. Кроме того, работники музеев и коллекционеры, по сути, вместе ведут важнейшую работу по атрибуции и экспертизе памятников, отделяя подлинное от многочисленных имитаций, копий и подделок, определяют варианты, находят изготовителей и уточняют время создания знаков.

Коллекция А. Л. Хазина уникальна своей системностью и полнотой представленных в ней экземпляров. Став доступной для исследователей и посетителей, она существенно расширила горизонты наших представлений, позволила увидеть новые варианты и типы знаков, отождествить носителей наград и внести новые страницы в их биографии. Рыцарские ордена Европы, как справедливо утверждает Л. М. Гаврилова [c. 13], оказывали воздействие на создание и трансформацию орденской системы Российской империи. Но вместе с тем и российская система наград, в свою очередь, существенно влияла на создание орденских систем многих государств, прежде всего Болгарии, Сербии, а затем и всех государств «социалистического лагеря».

Особое значение имеют т. н. объединенные звезды нескольких орденов, представленные в коллекции А. Л. Хазина. Как правило, они принадлежали монархам и представителям высшей знати. Среди таких звезд - комбинированная звезда ордена Св. Александра Невского и ордена Подвязки, с большой долей вероятности принадлежавшая либо Николаю II, либо его брату великому князю Михаилу Александровичу (№ 16). Ценность коллекции А. Л. Хазина состоит и в том, что в ней отождествлено и представлено несколько орденов, принадлежавших российским императорам или членам Российского императорского дома (№ 16, 43, 83) и ряду членов правящих домов государей Европы (британской королеве Виктории - № 10, герцогу Пармскому - № 195, королям Обеих Сицилий № 196, австрийским эрцгерцогам - № 200, 201, 205, 228, 231, прусским Гогенцоллернам - № 264, 265, вице-королю Индии - № 104).

Еще одним отличием коллекции А. Л. Хазина является наличие в ней большого числа орденских цепей (в экспозиции их представлено почти 40) - высших знаков наград, редко сохранившихся в частных да и в музейных собраниях.

К абсолютным раритетам можно отнести Малый знак редчайшего женского ордена Рабынь Добродетелей Священной Римской империи XVII в., ныне известный всего в трех экземплярах (№ 234).

Каталог содержит краткое изложение истории каждого ордена, награды рассматриваются в строгой иерархической последовательности, с 


\section{Исторический журнал: научные исследования № 2 (26) • 2015}

DOI: 10.7256/2222-1972.2015.2.16146

точным каталожным описанием знаков со всеми их особенностями (указанием названия, принадлежности определенному лицу, места, времени изготовления, имени мастера или фирмы, материала, техники изготовления, размеров, имеющихся клейм, инвентарных номеров). Примечательно, что при подготовке выставки и каталога был проведен тщательный пробирный анализ состава металлов наград, имеющий большое значение для атрибуции знаков, а также геммологический анализ драгоценных камней, их украшающих.

Особую и самостоятельную ценность имеют Приложения к книге. Это полезный и информативный список орденов Соединенного Королевства по их иерархии и с принятыми аббревиатурами обозначения кавалеров. Подобный справочный материал найти весьма непросто. Столь же информативен и полезен список фирм производителей орденов и их клейм. В Приложении 3 приведен наиболее полный список иностранных орденов, которыми были пожалованы российские императоры и императрицы. Подобный труд основан на тщательном исследовании с привлечением архивных материалов.

В качестве пожеланий, пожалуй, можно сделать только небольшие уточнения к переводам некоторых терминов, девизов и названий наград. Девиз ордена Свв. Михаила и Георгия «Auspicium Melioris Aevi» правильнее перевести не как «Предзнаменование лучших времен» [с. 102], а как «Предзнаменование лучшего века». Аббревиатуру на латинском языке титула королевы Виктории, помещенную на цепи Королевского Викторианского ордена (VICTORIA BRITT. REG. DEF. FID. IND. IMP.) следует читать как: «Виктория, королева британцев, защитница веры, императрица Индии». Слова «Божией милостью» [как на с. 113] в надписи отсутствуют. Надпись в цепи ордена Св. Стефана «Stringit amore» правильнее перевести не как «Любовь связует» [с. 250], а как «Связует любовью» (лат., творит. падеж, Ablativus). Равным образом и «Regi Apostolico» точнее перевести как «апосто- лическому королю», а не «равноапостольному». Девиз ордена Железной короны «Avita et aucta» следует перевести не как «унаследовал и преумножил» [с. 260], а как «унаследованная и преумноженная» (речь идет о короне, и грамматически - это два причастия). Ошибочен перевод девиза ордена Святого духа «Duce et auspice» как «Направляет и защищает» [с. 295]. Правильнее: «Под водительством и покровительством» (два существительных в творительном падеже, но не глаголы!). Девиз папского ордена Св. Григория Великого «Pro Deo et Principe» точнее перевести как «За Бога и Государя», а не «За Бога и Короля» [с. 406].

Девиз итальянского ордена Аннунциаты (Благовещения) FERT, возможно, не аббревиатура, вызывающая споры в интерпретации, а просто форма глагола fero, означающая «свершает» [1, 27-28].

К числу немногочисленных пропусков можно отнести отсутствие описаний истории учреждения и обстоятельств награждений британского Креста «За похвальную службу» (№ 170, 205) и цепи т. н. ордена Пия XII (№ 339). Последний, впрочем, является вариантом по сути единого Пианского ордена, Ordo Pianus, цепь которого как раз и была учреждена папой Пием XII.

Колодки (№ 309-310) и миниатюры германских наград (№ 270) точнее датировать не 1914-1918 или 1918-1919 гг., а периодом после 1934 г., т. к. в их числе - Почетный крест Первой мировой войны (Крест Гинденбурга), учрежденный в 1934 г.

Но эти незначительные поправки (число их обычно в разы больше при осуществлении подобного труда) не затеняют главного: перед нами прекрасно изданный альбом выдающихся наград выдающейся коллекции. Он полезен как любому человеку, интересующемуся историей, так и узкому специалисту в области фалеристики, работникам музеев, не говоря уже о том, что это драгоценный подарок для любителей наград не только в нашей стране, но и во всем мире.

\section{Библиография:}

1. Карпов С. П. Наградные системы мира. Фалеристика. М.: Аргамак-Медиа, 2014. 313 с.

\section{References (transliterated):}

1. Karpov S. P. Nagradnye sistemy mira. Faleristika. M.: Argamak-Media, 2014. 313 s. 